Table 1. Radiative conductivity (W/ $/ \mathrm{cm}^{\circ} \mathrm{K}$ )

Peridot (at $\left.1,513^{\circ} \mathrm{K}\right)$

Using room temperature spectral data $\quad 0 \cdot 446$

Using $1,513^{\circ} \mathrm{K}$ sp

Using room temperature spectral data
Usta

$\begin{array}{ll}\text { Using room temperature spectral data } & 0.516 \\ \text { Using } 1,513^{\circ} \mathrm{K} \text { spectral data } & 0.102\end{array}$

()ligoclase (at $1,303^{\circ} \mathrm{K}$ )

Ising room temperature spectral data

Using $1,303^{\circ} \mathrm{K}$ spectral data

$0 \cdot 425$

$0 \cdot 425$

valtes were calculated from near infrared optical properties as measured in this work.

a decrease in photon mean free path and thus radiative conductivity. The oligoclase, containing no $\mathrm{Fe}^{2+}$, shows a smaller decrease in radiative conductivity (a factor of about 1.7 at $1,300^{\circ} \mathrm{K}$ ) as the band broadening only occurs on the long wavelength side of the relevant wavelength region.

MacDonald ${ }^{1}$ was the first to indicate that estimates of the $1,500^{\circ} \mathrm{K}$ radiative conductivity less than $0.03 \mathrm{~W} / \mathrm{cm}$ ${ }^{\circ} \mathrm{K}$ appeared to be necessary in calculations of the thermal history of the Earth, although the values suggested by room temperature spectra of olivines were more than an order of magnitude larger. We believe that the results reported here go a long way towards resolving this apparent difficulty.

We thank L. A. McClaine and B. Peatie for their assistance and Professor C. Frondel for the samples of diopside and oligoclase. This work was supported in part by NASA, Manned Spacecraft Center.
J. R. Aronson
S. W. Eckroad
A. G. EMsLIE
R. K. MoConnell, JUN.
P. C. von ThÜNA

Arthur D. Little, Inc.,

Cambridge, Massachusetts.

Received Octover 18; revised November 20, 1967

${ }^{1}$ MacDonald, G. J. F., J. Geophys. Res., 64, 1967 (1959).

${ }^{2}$ Clark, jun., S. P., Trans. Amer. Geophys. Un., 38, 931 (1957).

${ }^{3}$ Clark, jun., S. P., Amer. Mineral., 42, 732 (1957). McConnell, jun., R. K., McClaine, L. A., Lee, D. W., Aronson, J. R., and
Allen, R. V., Rev. Geophys., 5, 121 (1967).

'Aronson, J. R., Emslie, A. G., McConnell, jun., R. K., Eckroad, S. W., and von Thüna, P. C., Trans. Amer. Geophys. Ün., 48, 211 (1967).

'Aronson, J. R., Jmslie, A. G., McConnell, jun., R. K., Eckroad, S. W., and von Thuina, P. C., Rep. NASA Manned Spaceeraft Center (Contract NAS $9-5840)(1967)$.

\section{Ordovician Graptolites from the Kashmir Himalayas}

THE discovery of graptolites near the village of Harpatnar in the Anantnag District of Kashmir ${ }^{1}$ was of considerable interest to geologists studying the history of the Himalayas, because the apparent absence of graptolites from the Himalayas had long been the subject of considerable debate and speculation. The graptolites (described in ref. 2) indicate a Ludlow (Late Silurian) age for the Harpatnar Beds from which they were collected ${ }^{2}$.

A continuous and apparently conformably stratigraphic succossion can be recognized stratigraphically above the highest graptolite-bearing layers in the Harpatnar Beds's, which are overlain by the Naubug Beds from which fish ${ }^{3}$ and conodont faunas ${ }^{4}$, indicative of an early Middle Devonian age, have been obtained. The stratigraphic succession beneath the lowest graptolite-bearing layer in the Harpatnar Beds is, in contrast with the layers above, faulted. Despite the structural complexities, a unit of red mudstones and shales can be recognized in a slice beneath the Harpatnar Beds which is bounded by faults. A collection of graptolites has recently been made by one of us (V.J. G.) from this slice.
The newly found graptolites are poorly preserved fragments. The following forms can, however, be recognized among them: Climacograptus sp.; Didymograptus sp. (juvenile stage of an extensiform didymograptid similar to $D$. compressus Harris and Thomas); Glossograptus ? sp. (a glossograptid, might be a paraglossograptid).

The association of this extensiform didymograptid with a climacograptid and glossograptid indicates an age span of late Early (approximately Late Arenig) into Middle (Mid-Caradoc) Ordovician. The association of extensiform didymograptids with climacograptids and glossograptids is known in the British and Continental European Ordovician graptolite successions from the British Didymograptus hirundo Zone and strata correlative with it into the Climacograptus bicornis Zone. This association of graptolites is known in the American-Australian-Asian Ordovician graptolite successions to range from beds, considered correlative with the basal part of the British Llanvirn, into those correlative with the British Climacograptus bicornis Zone.

The presence of the extensiform didymograptid, similar to $D$. compressus, suggests that the fauna may have had connexions with the American-Australian-Asian Ordovician graptolite faunas rather than the British-Continextal faunas. This didymograptid species is restricted to the American-Australian-Asian Ordovician graptolite fauna where it occurs in faunas considered to be correlated with those of the British Llanvirn.

These are the first conclusively Ordovician graptolites to have been found in this part of the Himalayas. Their presence in this area indicates that deposition of finegrained terrigenous materials took place, at least locally in the Himalayas, during at least a part of the Ordovician. These graptolites are the oldest fossils from the area south. east from Srinagar. Their presence thus indicates that marine deposition did take place in this part of the Himalayas and that, during at least a part of both the Ordovician and Silurian, graptolites were able to live in the waters in this area. The possibilities of the faunal connexion with the American-Australian-Asian graptolite faunas are significant to the palaeozoological distribution of Ordovician faunas. The Himalayan area may have been allied faunally with Asia during at least a part of the Ordovician.

University of California,

W. B. N. BERRY

Berkeley, California.

Panjab University,

Chandigarh, India.

\section{J, GuPTA*}

*At present. ICAS visitor in the Department of Gcology, Imperial Coll *as of Science and Technology, London.

Received November 7, 1967

' Sahni, M. R., and Gupta, V. J., Nature, 201, 385 (1964).

¿ Berry, W. B. N., and Gupta, V. J., J. Paleont., 40, 1338 (1966).

${ }^{3}$ Gupta, V. J., and Denison, R. H., Nature, 211, 177 (1966).

-Gupta, V. J., Rhodes, F. H. T., and Austin, R. L., Nature. 216, 468 (1967).

\section{PHYSICS}

\section{Bursting Air Bubbles studied by the Time Exposure Technique}

THERE are several mechanisms by which particulate matter is transferred across the sea-air interface. Filaments of liquid are torn from the tops of whitecaps by the wind and are generated by the break-up of combers. The mechanism of greatest meteorological importance is, however, the bursting, at the interface, of bubbles of air which have been trapped under the water surface or have been released from solution. 